\title{
Nonexchangeable Site
}

National Cancer Institute

\section{Source}

National Cancer Institute. Nonexchangeable Site. NCI Thesaurus. Code C13447.

A binding site where a lig and is permanently bound. 